\title{
Pemanfaatan UMKM Melalui Media Sosial pada Masa Covid 19
}

Erdiansyah $^{1}$, Ninin Non Ayu Salmah ${ }^{2}$, Muhammad Kurniawan ${ }^{3}, \mathrm{Hj}$. Maliah $^{4}$, Nisa Ulul Mafra ${ }^{5}$, Benny Usman ${ }^{6}$, Sundari ${ }^{7}$, Agus Mulyani ${ }^{8}$

${ }^{1-8}$ Program Studi Manajemen, Akuntansi dan Bisnis Digital Universitas PGRI Palembang

e-mail: ${ }^{1}$ erdiansyahhh@gmail.com, ${ }^{2}$ nininonayu@gmail.com, ${ }^{3}$ agusmulyani008@gmail.com

\begin{abstract}
ABSTRAK Covid-19 berdampak ke segala sektor, salah satunya sektor ekonomi. Hal ini dirasakan secara signifikan oleh para pelaku Usaha Mikro Kecil Menengah (UMKM) yang mengalami krisis ekonomi. Pasalnya, menurunnya daya beli masyarakat akibat pandemi Covid-19 juga sangat berpengaruh terhadap keberlangsungan usaha UMKM. Krisis ekonomi yang dialami UMKM tanpa disadari dapat menjadi ancaman bagi perekonomian nasional. Oleh karena itu pembinaan dan bantuan untuk pelaku UMKM di masa pandemi perlu menjadi perhatian banyak sektor terutama lembaga pemerintah. Tujuannya membuat Indonesia mampu bertransformasi menjadi negara maju juga menyimpan ancaman, bahwa negara kita hanya akan menjadi pasar (konsumen) ekspansi dari industri pada tingkat global karena ketidakmampuan kita untuk bersaing dan berinovasi. Metode yang digunakan penyuluhan/ceramah, praktik.
\end{abstract}

KATA KUNCI. UMKM; Penyuluhan; Covid-19

ABSTRACT Covid-19 has an impact on all sectors, one of which is the economic sector. This is felt significantly by micro small and medium enterprises (MSMEs) who are experiencing an economic crisis. The reason is, the decrease in people's purchasing power due to the Covid-19 pandemic is also very influential on the sustainability of MSME business. The economic crisis experienced by MSMEs can unwittingly become a threat to the national economy. Therefore, coaching and assistance for MSMEs in pandemic times needs to be a concern for many sectors, especially government agencies. he goal of making Indonesia able to transform into a developed country also harbors the threat, that our country will only become a market (consumer) expansion of the industry on a global level because of our inability to compete and innovate. Methods used extension / lectures, practices.

\section{KEYWORDS. MSMEs; Counseling; Covid-19}

\section{Pendahuluan}

Perkembangan teknologi yang semakin canggih, dunia kini memasuki era revolusi industri 4.0, yakni menekankan pada pola digital economy, artificial intelligence, big data, robotic, dan lain sebagainya atau dikenal dengan fenomena disruptive innovation. Menghadapi tantangan tersebut, pengajaran di perguruan tinggi pun dituntut untuk berubah, termasuk dalam menghasilkan sumber daya manusia berkualitas bagi generasi masa depan. Langkah ini penting karena belum banyak yang berminat memahami Industri 4.0. Masyarakat memang sudah melakoni beberapa perubahan itu, tetapi kepedulian pada tantangan di era digitalisasi dan otomasi sekarang ini pun terbilang minim. Hal itu menjadi pertanyaan mendasar yang harus dijawab oleh setiap pemuda saat ini. Bagaimana cara pemuda mampu survive dalam mengembangkan diri, menciptakan lapanganlapangan pekerjaan, menginisiasi industri kreatif, dan berperan aktif dalam 
perekonomian kita, baik secara mikro ataupun makro. Pemuda Indonesia tidak boleh hanya menjadi penonton dalam 'persaingan' global, terutama pada bidang ekonomi. Bonus demografi yang digadang-gadang akan membuat Indonesia mampu bertransformasi menjadi negara maju juga menyimpan ancaman, bahwa negara kita hanya akan menjadi pasar (konsumen) ekspansi dari industri pada tingkat global karena ketidakmampuan kita untuk bersaing dan berinovasi. Masalah ini menjadi pekerjaan rumah kita bersama, tidak hanya dibebankan kepada pemerintah, namun seluruh stakeholders yang peduli dengan bangsa dan negara kita. Tantangan zaman kita tidak hanya pada persaingan dan ekspansi ekonomi global, namun juga pada fenomena revolusi industri 4.0. Sejatinya, ketika hal ini tidak diberikan perhatian yang serius dan lebih, maka bonus demografi yang akan dimiliki bangsa Indonesia menjadi tidak ada artinya. revolusi indutri 4.0 akan berpotensi besar mengubah 'tatanan' kehidupan manusia, dimana dampaknya sedikit demi sedikit sudah terlihat di era saat ini.

Negara harus mengambil inisiatif mendorong semua elemen masyarakat lebih peduli era Industri 4.0. Dengan memberi pemahaman yang lebih utuh dan mendalam, masyarakat dengan sendirinya akan terdorong untuk bersiap menghadapi sekaligus merespon perubahan-perubahan dimaksud.

PKM menjadi sangat penting adalah mendorong sektor pendidikan nasional dari pendidikan dasar hingga pendidikan tinggi untuk menyesuaikan kurikulum pendidikan dengan tantangan dan kebutuhan pada era sekarang ini. Kurikulum yang membuka akses bagi generasi milenial mendapatkan ilmu dan pelatihan untuk menjadi pekerja yang kompetitif dan produktif.

Untuk menjawab tantangan tersebut salah satu bentuk aktualisasi tugas dosen sebagai tenaga profesional adalah diterbitkannya Undang-undang Nomor 20 Tahun 2003 tentang Sistem Pendidikan Nasional, Undang-undang No. 14 Tahun 2005 tentang Guru dan Dosen dan Peraturan Pemerintah No. 19 Tahun 2005 tentang Standar Nasional Pendidikan. Undang-Undang dan Peraturan pemerintah ini diharapkan dapat menfasilitasi guru dan dosen untuk selalu mengembangkan keprofesionalannya secara berlanjut. Peran, tugas, dan tanggung jawab dosen diimplementasikan melalui pelaksanaan Tridarma Perguruan Tinggi. Dosen harus memiliki kompetensi yang menunjukkan sikap profesionalisme karena akan menentukan kualitas pelaksanaan Tridarma Perguruan Tinggi yaitu pelaksanaan Pendidikan, Penelitian, dan Pengabdian Kepada Masyarakat.

Tridarma Perguruan Tinggi harus dilaksanakan secara terus menerus dan berkesinambungan sehingga kualitas setiap dosen akan semakin baik. Salah satu komponen Tridarma Perguruan Tinggi adalah Pengabdian Kepada Masyarakat. Kegiatan Pengabdian kepada Masyarakat ini membantu guru dan siswa paham akan manfaat media sosial untuk memulai berwirausaha dan juga memungkinkan dosen untuk berinteraksi dengan masyarakat sehingga akan memberikan kontribusi positif bagi masyarakat khususnya guru dan siswa SMAN 7 Prabumulih yang akan berwirausaha di masa covid-19 ini.

\section{Metode}

Kegiatan Pengabdian Pada Masyarakat ini dilaksanakan secara tim oleh dosendosen Program Studi Bisnis Digital, Manajemen dan Akuntansi Fakultas Ekonomi dan Bisnis Universitas PGRI Palembang dengan tema umum "Pemanfaatan UMKM Melalui Media Sosial Pada Masa Covid 19". Kegiatan yang dilakukan berupa penyuluhan/ceramah dan pelatihan langsung kepada guru-

Pemanfaatan UMKM melalui Media Sosial pada masa Covid-19..... Erdiansyah 
guru dan siswa di lingkungan SMAN 7 Kota Prabumulih. Pelatihan dilaksanakan dalam enam tahapan berikut:

\subsection{Tahap Persiapan}

Tahap ini terdiri atas beberapa kegiatan yang di mulai dengan penyusun Pengabdian Kepada Masyarakat (PKM) dan berkoordinasi dengan pihak SMAN 7 Kota Prabumulih untuk menyamakan persesi dan memperoleh informasi secara umum mengenai Penyuluhan yang telah dilaksanakan. Sementara itu mempersiapkan materi yang akan di sampaikan dalam penyuluhan tersebut. Kemudian dengan persetujuan dari Dekan Fakultas Ekonomi dan Bisnis membuat dan menyampaikan Proposal Pengabdian kepada Rektor Universitas PGRI Palembang melalui LPPKMK Universitas PGRI Palembang.

2.2. Tahap Sosialisasi

Tim pelaksana akan memberikan sosialisasi berupa gambaran kegiatan PKM yang akan dilaksanakan kepada siswa. Kegiatan ini dilaksanakan dengan metode ceramah, tanya jawab dan pelatihan.

2.3. Tahap Pelatihan

Pada tahap ini dilaksanakan dalam bentuk pelatihan. Materi pelatihan bagaimana menggunakan media sosial yang benar untuk berwirausaha.

2.4. Tahap Pengecekan

Tim pelaksana PKM akan mengecek perkembangan tahapan memulai atau menggunakan media sosial.

2.5. Tahapan Diskusi

Guru dan siswa telah memahami tujuan dari cara menggunakan dan memanfaatkan media sosial dalam berwirausaha.

2.6. Tahapan Evaluasi Kegiatan

Tim pelaksana dan peserta akan berdiskusi tentang tentang sejauh mana tingkat keberhasilan program, kendala atau masalah yang dihadapi selama kegiatan berlangsung dan saran serta tindak lanjut yang diambil setelahnya

\section{Hasil dan Pembahasan}

Berdasarkan kegiatan penyuluhan dan sosialisasi yang telah dilaksanakan ditengah - tengah siswa-siswi dan guru SMA Negeri 7 Prabumulih, hasilnya siswa-siswi dan guru SMA Negeri 7 Prabumulih, mendapatkan beberapa manfaat seperti mendapatkan pengetahuan bagaimana memulai berwirausaha, memasarkan produk-produk yang dihasilkan melalui media sosial yang ada, dan bagaimana cara penjualan di masa covid-19 yang tidak bisa kita menjual secara langsung.

Sebelumnya siswa-siswi dan guru SMA Negeri 7 Prabumulih masih belum tahu bagaimana cara memulai untuk menjadi wirausahawan yang bisa memanfaatkan media sosial yang sekarang lagi trend, dan lagi digemari oleh anak-anak muda di zaman sekarang ini, apa lagi sekarang dimasa pandemi ini penjual dan pembeli itu harus menerapkan protokol kesehatan yang dianjurkan pemerintah.

Setelah diberikan pemahaman terhadap siswa-siswi dan guru SMA Negeri 7 Prabumulih melalui penyuluhan dan sosialisasi yang dilakukan oleh Dosen bersama mahasiswa, yang hasilnya siswa-siswi dan guru SMA Negeri 7 Prabumulih telah memahami dan telah termotivasi untuk memulai berwirausaha walaupun mereka masih muda dan sudah mau membuka lapangan pekerjaan untuk kawan-kawannya yang lain, dan mereka juga sudah tahu bahwa di dalam $\overline{\text { Erdiansyah......Pemanfaatan UMKM melalui Media Sosial pada masa Covid-19 }}$ 
memasarkan produk yang mereka tidak harus bertemu dengan konsumennya akan tetapi bisa dan sangat mudah untuk meggunakan media sosial, baik itu Instagram, Whatshapp, Facebook, maupun market place yang ada banyak sekarang ini. Tindakan siswa-siswi dan guru SMA Negeri 7 Prabumulih, sudah mulai dengan membuat aplikasi seperti IG (Instagram) Bisnis, dll, untuk mempermudah mereka dalam memasarkan produk yang akan mereka buat.

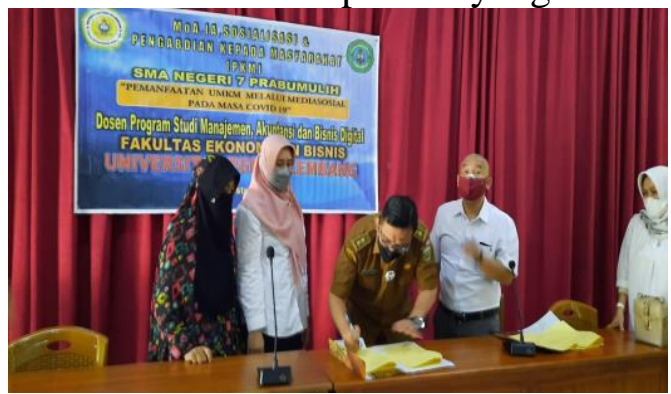

(a) Kegiatan penyuluhan dan sosialisasi pemanfaatan UMKM melalui media sosial di SMA Negeri 7 Prabumulih

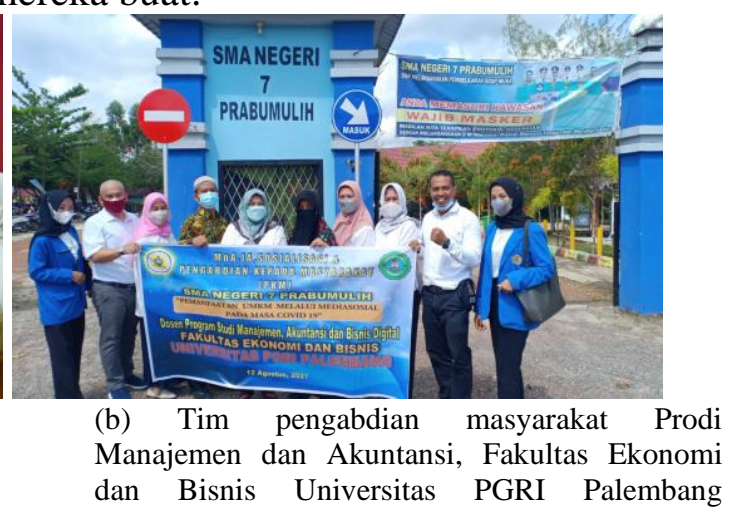

\section{Kesimpulan}

Penyuluhan ini membuka wawasan pada siswa-siswi SMA Negeri 7 Kota Prabumulih bahwa untuk peluang berwirausaha online. Berdasarkan kegiatan penyuluhan yang telah dilakukan, juga diketahui bahwa masih banyak kalangan masyarakat yang menganggap untuk memulai suatu usaha itu sulit. Padahal ada trik agar berwirausaha itu dimulai dari kreatifitas pada diri sendiri dengan mengidentifikasi gagasan dan orientasi tindakan memanfaatkan kreatifitas yang dimiliki oleh siswa-siswi SMAN Negeri 7 Kota Prabumulih.

\section{Ucapan terima kasih}

Kami mengucapkan banyak terima kasih kepada para peserta yang telah berpartisipasi dalam kegiatan pengabdian kepada masyarakat ini. Kami juga menyampaikan terima kasih kepada jajaran pimpinan SMAN Negeri 7 Kota Prabumulih atas dukungan moril dan finansial kepada tim pengabdi.

\section{Daftar pustaka}

[1] R. Lupiyoadi, Manajemen Pemasaran Jasa. Jakarta: Salemba Empat, 2001.

[2] Indonesia, Undang-undang Nomor 20 Tahun 2003 tentang Sistem Pendidikan Nasional. Indonesia, 2003.

[3] Indonesia, Undang-undang No. 14 Tahun 2005 tentang Guru dan Dosen. Indonesia, 2005.

[4] Indonesia, Peraturan Pemerintah No. 19 Tahun 2005 tentang Standar Nasional Pendidikan. Indonesia, 2005.

[5] L. G. Schiffman dan L. L. Kanuk, Consumer Behavior. Fifth Edition. New Jersey: Prentice Hall, 2007.

[6] J. P. Peter dan J. C. Olson, Consumer Behavior: Perilaku Konsumen dan Strategi Pemasaran. Jakarta: Erlangga, 2008.

[7] P. Kotler dan K. L. Keller, Manajemen Pemasaran Jilid 1. Jakarta: Erlangga, 2008.

[8] Kementerian Pendidikan Nasional, Bahan Pelatihan Penguatan Metodologi Pembelajaran Berdasarkan Nilai-nilai Budaya untuk 
Membentuk Daya Saing dan Karakter Bangsa. Jakarta: Badan Penelitian dan Pengembangan Pusat Kurikulum Kementerian Pendidikan Nasional, 2010 .

[9] Kementerian Pendidikan Nasional, "Pengembangan Iptek dan Pendidikan Tinggi di Era Revolusi Industri 4.0,” 2018. www.ristek.dikti.go.id (diakses Sep 12, 2018).

[10] B. Alma, Manajemen Pemasaran dan Pemasaran Jasa. Bandung: Alfabeta, 2013.

[11] Sunyoto, Perilaku Konsumen Teori dan Penerapan Dalam Pemasaran. Jakarta: Ghalia Indonesia, 2013.

[12] P. Kotler dan G. Amstrong, Dasar-Dasar Pemasaran, Edisi 9 Ji. Jakarta: PT Indeks kelompok Gramedia, 2013.

[13] F. Tjiptono, Pemasaran Esensi dan Aplikasi. Yogyakarta: Andi Offset, 2016.

[14] Kemenristekdikti, "Era Revolusi Industri 4.0, Saatnya Generasi Millennial Menjadi Dosen Masa Depan," 2018. .

[15] A. Sofjan, anajemen Bisnis Pemasaran. Jakarta: Rajawali Press, 2019.

[16] Suryana dan P. Yoga, Cara Mudah Bisnis di Era Industri 4.0. Jakarta: Salemba Empat, 2020.

$\overline{\text { Erdiansyah......Pemanfaatan UMKM melalui Media Sosial pada masa Covid-19 }}$ 